\title{
A Review of Khitan Language Materials
}

\section{Kıtan Dilinde Yazılmış Materyallere Genel Bakış}

\author{
Kubilay ATIKK ${ }^{1}$ (])
}

'Nevşehir Hacı Bektaș Veli University, Department of History, Nevşehir, Turkey

\section{ORCID: K.A. 0000-0001-7657-6645}

Corresponding author/Sorumlu yazar: Kubilay ATiK (Asst. Prof.),

Nevşehir Hacı Bektaş Veli University, Department of History, Nevşehir, Turkey

E-mail:kubilayatik@gmail.com

Submitted/Başvuru: 06.02.2021

Revision Requested/Revizyon Talebi:

08.02.2021

Last Revision Received/Son Revizyon: 26.03.2021

Accepted/Kabul: 26.03.2021

Citation/Atıf: Atik, Kubilay. "A Review of Khitan Language Materials". Şarkiyat Mecmuası - Journal of Oriental Studies 38 (2021), 125-136.

https://doi.org/10.26650/jos.875458

\begin{abstract}
The Khitan people, who have now disappeared for a long time, were an important group during the medieval period in East and Central Asia. Despite having established the Liao Dynasty and the Qara Khitai states, their language and script were forgotten following the Mongol conquests and they were largely assimilated by the Mongols. As a matter of fact, Yelü Chucai was perhaps the most famous Khitan of his time, and in modern times, studies on Yelü Chucai surpass those on Abaoji, the founder of the Liao dynasty. He has been presented as a great intellectual by his Chinese, Mongol and Khitan contemporaries as well as modern historians. However, this article aims to demonstrate that there was nothing extraordinary about a Khitan being on par with his Han Chinese, Persian or Central Asian counterparts intellectually by the time of Chucai, and his success was a culmination of over a century of Khitan tradition in both Khitan and Chinese. This study introduces and examines the development of the written tradition in the Khitan language and aims to demonstrate that Yelü Chucai was not an exception, but rather the norm by the time of Jinggis Qaghan, who called him "urtuq saqal". The approach to Khitan literature was divided along historical period lines rather than linguistic lines. The Khitan words and titles have been written in Latin letters, since it was not possible to write them in either Khitan scripts.
\end{abstract}

Keywords: Khitans, Khitan Intellectuals, Khitan Literature, Liao Dynasty, Khitan Language

\section{Öz}

Uzun süre önce ortadan kalkmış olan Kıtan halkı orta çağda Doğu Asya ve Orta Asya'da önemli bir topluluktu. Liao Hanedanı ve Kara Hıtay devletini kurmalarına karşın dilleri ve yazıları Moğol fetihleri sonrasında büyük oranda Moğolların arasında asimile olmaları sonucunda unutulmuştur. Aslına bakılırsa Yelü Chucai belki de döneminin en ünlü Kıtanı idi, ve çağdaş dönemde de Yelü Chucai üzerine araştırmalar neredeyse Liao Hanedanının kurucusu olan Abaoji'yi geçmektedir. Yelü Chucai çağdaşı olan Moğol, Çinli ve Kıtanlar ve de günümüz tarihçileri tarafından büyük bir aydın olarak görülmektedir. Ancak bu makale bir Kıtan'ın bu dönemde Çinli, İranlı, ya da Orta Asyalı meslektaşlarından entelektüel olarak çok farklı olmadığını ve bir yüzyıldan daha uzun süredir gelişen Kıtan yazı geleneğinin bu durumun nedeni olduğunu gözler önüne sermeyi amaçlamaktadır. Bu çalışma Kıtan dilinde yazılmış olan edebiyat geleneğinin gelişimini incelemektedir ve Cengiz Kağan tarafından "urtuk sakal” olarak adlandırılan Yelü Chucai dönemine 
gelindiğinde Kıtanların artık son derece gelişmiş bir yazın geleneğine sahip olduğunu ve Yelü Chucai'yın bir istisnadan çok bir norm olduğunu göz önüne sermeyi amaçlamaktadır. Bu çalışmada Kıtan yazınına olan yaklaşım dilbilim temelli olarak değil metinlerin yazıldığı dönem göz önüne alınarak dönemsel olarak bölümlere ayrılmıştır. Kıtan dilindeki unvan ve sözcükler Kıtan karakterleri ile aktarım mümkün olmadığından Latin alfabesi ile aktarılmıştır.

Anahtar kelimeler: Kitanlar, Kitan Aydınlar, Kitan Yazını, Liao Hanedanı, Kitan Dili 


\section{Introduction}

The Khitans were originally semi-nomadic people living on the southern edge of Manchuria around the mouth of Liao river. During the Tang dynasty, they were pressed between the Türk ${ }^{1}$ Qaghanate and the Tang pledging their allegiance to one or the other side. However, both sides would attack the Khitans whenever the Khitans began to gain strength and pose a threat to the balance of power. After the collapse of the Türk Qaghanate, the Khitans became vassals of the Uighur Qaghanate. As a result of the collapse of both the Goguryeo (高句麗) state in Manchuria and the Tibetan Empire, the balance of power that had been established between the steppe and China was rendered useless. Until that time, the Goguryeo state in Manchuria balanced the Tang and Türk Qaghanate in the east, allying with the weaker party, and the Tibetans used the same strategy in the west. Thus, there was a delicate balance of power which no party wanted to upset. ${ }^{2}$ As a result, whenever a new power, such as the Khitans or the Tuyuhun would begin to rise, these states would even ally with each other to crush the rising power. However, when all these states collapsed, with the exception of the Tang dynasty, which was in no position to hinder the Khitans from strengthening their position in Manchuria after An Lushan's rebellion, using Khitan cavalry, the Khitans swiftly overcame their opponents ${ }^{3}$. Following the collapse of the Tang Dynasty in China as a result of the An Lushan and Huangchao rebellions, China disintegrated into nine kingdoms in the south and five consecutive dynasties in the north. On the steppe, there was a power vacuum following the collapse of the Uighur Qaghanate as a result of a Kyrgyz attack on their capital. In the meantime, the Khitan tribes were being united under the leadership of the Yelü tribe. The Ximo and Kumoxi tribes, as well as the Uighur tribes who had taken shelter among the Khitans after the defeat of their Qaghanate, joined this new state. As can be seen, the new Khitan state was multi-ethnic and multilingual in nature from the very beginning. The linguistic and ethnic composition of this new state became further complicated after the conquest of Balhae, a Korean state in Manchuria. Balhae was the successor to the Goguryeo kingdom, in roughly the same area, with the exception of the Northern part of Korea, and the steppe area further west, the conquest of which was stopped only by the Tangut Xi Xia state in the Ordos region. Finally, the conquest of the thirteen prefectures in the Yan province of China, which became a political crisis for the Song dynasty until its demise at the hands of the Mongols, set the final border of the Khitan State, which by this time had become the Liao dynasty. These expansions and the inclusion of the elites of these areas into the Khitan elite was also reflected in the Khitan language and literary tradition, as well as the administrative and political culture of the state.

1 Türk is used for the political entity called as the Tujue/突厥 by the Chinese while Turk and Turkic are used for the Turkic peoples. In order not to cause any confusion "ü̈" was used for the state and the political entity.

2 Kubilay Atik, "A Comparison of Komnenos Era Byzantine and Song Era Chinese Diplomacy with Nomadic Neighbors," Atatürk Üniversitesi Türkiyat Araştırmaları Enstitüsü Dergisi 70, no. 1 (2021): 347, http://www. turkiyatjournal.com/DergiTamDetay.aspx?ID=4433.

3 Jonathan Karam Skaff, "Barbarians at the Gates? The Tang Frontier Military and the An Lushan Rebellion," War \& Society 18, no. 2 (2000): 26, http://www.maneyonline.com/doi/abs/10.1179/072924700791201658. 
In the administrative area, the Khitans demonstrated a dual structure after the conquest of the Balhae (渤海) Kingdom, a Korean kingdom which was the successor to the great Goguryeo state in the same area with the exception of Northern half of the Korean peninsula. The Khitans emulated the Korean practices, such as the five capitals system, with a central government in the central capital and local governments in the four directional capitals. These local capitals had slight variations which enabled flexibility to local government practices. However, this does not necessarily mean that the Khitan state was structured on the exact same model of the Korean states, or Chinese models later on for that matter. The central capital was governed by a Khitan from the Yelü tribe or an Uighur from the Xiao (蕭) clan in the absence of the emperor. The eastern capital, which was in the former Balhae region, would be governed by a Balhae aristocrat, or a Khitan aristocrat from the Yelü tribe, but regardless of whoever sat on the seat of government in the eastern capital, former Balhae practices were continued to a great extent. The southern capital in the former Yan province of China would always be entrusted to a Yelü or a Xiao aristocrat since this was the most populous and one of the wealthiest parts of the empire. The western capital, which was in the steppe area among the nomad tribes, was governed by an Uighur Xiao aristocrat in accordance with the previous Türk and Uighur practices, while the northern capital in the forest areas of Manchuria (which was inhabited by the Jürchen tribes who would prove to be the most problematic subjects of the empire and who finally brought about the destruction of the Khitan Empire) was entrusted to the Xiao clan members, who also served as prime ministers. Thus, other than the Khitans, there were influential elements from the Uighur, Korean and Chinese elite of the empire which were not only reflected in the administration and sharing of power of the empire, but also in the written Khitan tradition, which developed in accordance with these influences, as will be discussed further.

\section{Literature Review}

Among the so-called "alien" regimes of China, Khitans and the Liao dynasty are perhaps the least studied. Although the name of China in many western languages was derived from them and remains so in many of the Turkic and Slavic languages, this topic has been often overshadowed by their successors, the Jürchens and Mongols. However, beginning with the identification of some Khitan script books, which were thought to be in a "strange Chinese", interest in Khitan history, language, literature and social structure has increased. Due to the limited space of this article and in order not to stray too far from the topic, the literature review is limited to the last two decades of scholarship on the Khitans, in order to give an overview to the general reader. The specialized reader will undoubtedly know the stupendous volume of works since the early twentieth century in Russian, Japanese, Chinese, English, and other western languages on the topic. Shimunek's work ${ }^{4}$ on the Khitan language is one of the recent

4 Andrew E. Shimunek, Towards a Reconstruction of the Kitan Language, with Notes on Northern Late Middle Chinese Phonology (Bloomington: Indiana University, Department of Linguisitcs and the Department of Central Eurasian Studies, 2007). 
works reconstructing the now dead Khitan language. Other recent works on the topic include Kane's work ${ }^{5}$, which gives an introduction to the language and the literature of the Khitans. Of further importance is Wu and Janhunen's work, which give one of the largest introductions to the recent discoveries on the Khitan language manuscripts, titled "New Materials on the Khitan Small Script: A Critical Edition of Xiao Dilu and Yelü Xiangwen" which gives information and some translations on the contents of the newly discovered documents in the Khitan small script, which will be discussed further. ${ }^{6}$ Naomi Standen's work ${ }^{7}$ on the Liao Dynasty has also been valuable in contributing to the field. She has contributed to the field of the Liao dynasty and Khitans through her masterful analysis of the Chinese sources written during and after the Liao dynasty. ${ }^{8}$ In Russia Nikolay Kradin's works on the Khitans and the Liao dynasty are among the most recent studies on the Khitans, along with Zaitsev and others, which demonstrates the fact that Russia remains among the important centers for Khitan studies. ${ }^{9}$

\section{Liao Tradition}

The Khitans lived on the border between the steppe and China. As a result, they were influenced by both the Turkic peoples to their north and the Chinese to their south, both politically and culturally. It is curious that, until the arrival of the Mongols, nearly all the pastoral nomadic or semi-nomadic peoples who established a state in the steppe or Manchuria created their own writing systems, instead of directly borrowing from their predecessors. The Mongols and their Manchu successors were exceptions, who used a borrowed Uighur script with slight variations. Although there are Chinese reports on the existence of a written system of the Huns, the earliest

5 Daniel Kane, The Kitan Language and Script, vol. 166 (Leiden: Brill, 2009).

6 Yingzhe Wu and Juha Janhunen, New Materials on the Khitan Small Script A Critical Edition of Xiao Dilu and Yelü Xiangwen, Corpus Scriptorum Chitanorum 1 (Kent: Global Oriental, 2010).

7 Naomi Standen, Unbounded Loyalty: Frontier Crossings in Liao China (Honolulu: University of Hawaii Press, 2007).

8 Ibid.

9 Nikolai N. Kradin and Stanislav Prokopets, Великая Киданьская Стена: Северо-Восточный Вал Чингис-Хана (Moscow: Nauka, 2019); Vasiliy Petrovich Zaitsev, "Рукописная Книга Большого Киданьского Письма Из Коллекции Института Восточных Рукописей РАН [Rukopisnaya Kniga Bol'shogo Kidan'skogo Pis'ma Iz Kollektsii Instituta Vostochnykh Rukopisey RAN]," Письменные Памятники Востока [Pis 'mеппууе Pamyatniki Vostoka: Written Monuments of the Orient], no. 2 (2011): 15; Vyacheslav Petrovich Zaitsev, “Идентификация Киданьского Исторического Сочинения В Составе Рукописной Книги-Кодекса Nova Н 176 Из Коллекции Ивр Ран И Сопутствующие Проблемы [Identifikatsiya Kidan'skogo Istoricheskogo Sochineniya V Sostave Rukopisnoy Knigi-Kodeksa Nova N 176 Iz Kollektsii Ivr Ran I Soputstvuyushchiye Problemy],” Acta Linguistica Petropolitana-Trudy Instituta Lingvisticheskikh Issledovaniy 11, no. 3 (2015): 167-208, http://www.academia. edu/download/40789881/zaytsev_2015.pdf; Vsevolod Sergeyevich Taskin, “Опыт Дешифровки Киданьской Письменности [Opyt Deshifrovki Kidan'skoy Pis'mennosti: Experience Deciphering Khitan Script], ” Narody Azii i Afrikii, no. 1 (1963); L. N. Rudov, “Проблемы Киданьской Письменности,” Сов. Этнография, nо. 1 (1963); Vladimir Ernstovich Shavkunov, "К Вопросу о Расшифровке Малой Кидань-Чжурчжэньском Письменности [K Voprosu o Rasshifrovke Maloy Kidan'-Chzhurchzhen'skom Pis'mennosti: On the Issue of Deciphering Khitan Small-Jurchen Writing], "Eppgrafnka Vostoka 15 (1963); John Tan, “О ДВУХ ЗНАКАХ КИДАНЬСКОГО ПИСЬМА, ОТНОСЯЩИХСЯ К ЖЕЛЕЗУ,” ACTA LINGUISTICA PETROPOLITANA. ТРУДЫ ИНСТИТУТА ЛИНГВИСТИЧЕСКИХ ИССЛЕДОВАНИЙ 11, no. 3 (2015): 465-70, http://elibrary. $\mathrm{ru} / \mathrm{item} . \mathrm{asp}$ ?id=25462828. 
examples we have are from the Türks who had a profound influence on their successors. The Türk runic script, however, was only adopted by the Uighurs and other Turkic peoples and a group of Yeniseic ${ }^{10}$ speakers in Siberia. The Uighurs later on created the Uighur script, which was derived from Sogdian, which in turn was derived from the Syriac alphabet. However, the succeeding Khitan, Tangut and Jürchen states created their own writing systems instead of simply borrowing the Turkic runes or the Uighur script. The reason for this choice is ambiguous. However, there seems to be a pattern of writing in the native language among the Khitans and their Tangut neighbors. The Tanguts even wrote their laws in the Tangut script ${ }^{11}$. Although there are no examples of law codex or digests written in Khitan language either in large or small script, it is possible that the Khitans used their scripts to record their administrative and legal proceedings as well. As Standen has pointed out, there was not an ethnic sense of superiority or nationalism in a modern sense among the Khitans. ${ }^{12}$ In fact, from the very beginning, the Khitans were a multi-ethnic confederation containing Shiwei, Ximo, Uighur and other elements. Therefore, the reason for creating a writing system to record in the native language of the Khitans would have had other reasons. One reason could be emulating the Türk and Uighur traditions, thus creating an ideological bridge in the eyes of their nomadic subjects. It is significant that the great majority of the artifacts written in Khitan large script, which was created during the reign of the first Khitan emperor Abaoji, who not only unified the Khitans and established an independent Khitan state for the first time, but also claimed equality to the Chinese emperors and the previous Uighur Qaghanate. Just like the Türks and Uighurs, the Khitans erected stelae in the steppe and sometimes the capital cities (the Khitans had five capitals in the Korean manner). The large Khitan script, however, was styled after the Chinese script and was mostly based on logographs. But some characters also corresponded to sounds or syllables, which were used for grammatical purposes or for writing names. This system might seem to be reminiscent of modern Japanese in many ways. However, unlike Japanese, which uses kana for grammatical purposes and writing loan words and foreign names, alongside Kanji, which is borrowed from Chinese and kept intact to a great extent, the Khitan large script writing system seems to be more similar to the Korean Idu writing system. The Idu system was used in Korea to write down the Korean language using Chinese characters. Being an Altaic language like Khitan, Korean is an agglutinative language, which requires suffixes to demonstrate the cases or verb conjugations and tenses etc. Therefore, Koreans would use Chinese characters both as logograms to convey the meaning, and as phonemes to convey syllables corresponding to grammatical elements. They were also used as phonemes

10 Yeniseic languages are a gro up of languages most of which are today extinct. These languages were spoken in a wider area during the ancient period, possibly stretching all the way to Mongolia and Northern China. (For details see: Alexander Vovin, "Did the Xiongnu Speak a Yeniseian Language," Central Asiatic Journal 44, no. 1 (2000): 87-104.)

11 Kubilay Atik, “Ortaçağ Bozkır Devletlerinde Hayvancılık Üzerine Yasalar: Tangut Devleti Örneği,” Erzincan Üniversitesi Sosyal Bilimler Enstitüsü Dergisi 13, no. 2 (2020): 183-98, doi:https://doi.org/10.46790/ erzisosbil.798191.

12 Standen, Unbounded Loyalty: Frontier Crossings in Liao China. 
to write down personal names, nouns or native Korean words. Such a system is not specific to Korea; it can also be seen in Vietnam and Laos, and even among the Sinitic languages. For instance, in Minnan, which is spoken in Fujian, Taiwan, Singapore, Hainan and the Chinese diasporas in South East Asia and the USA, a similar system of writing is used. For instance in Amoy (Xiamen) Minnan, limbé means father, and it is written with the Chinese characters 林杯 (lin bei in Mandarin), which mean forest and cup. Thus, a native Chinese (Mandarin) speaker would have difficulty in comprehending the meaning of a text written in such a system, even if they were all written in Chinese characters in a Sinitic language, considered by many linguists to be a dialect of Chinese, rather than a separate language. However, such a system was bound to be impractical and cause confusion for most readers. Nonetheless, the Koreans used Idu until Hangul became widespread, and Khitans used the large script until the small Khitan script (which was based on the Uighur script and was more convenient to write down) gradually supplanted it. Apart from the technical side of the Khitan large script, it is significant that it was mainly used in writing epigraphs and stelae like the Türk and Uighur Stelae. In this respect, it is possible that the first Khitan emperor Abaoji was actually trying to emulate the Türks and Uighurs who erected bilingual epigraphs as political testimonies to their power and legitimacy. This message was aimed more at their nomadic subjects in the steppe rather than their Korean Balhae or Chinese subjects in Yan. The Khitan elite seem to have been acquainted with the Chinese language and writing as early as the Tang dynasty. For these reasons, the large Khitan script epigraphs might have been mostly aimed at the nomadic subjects to demonstrate to them that the Khitans could culturally surpass their previous Türk and Uighur masters. There are no studies on the extent of literacy among the Türk, Uighur or Liao nomadic populations. However, the Chinese records demonstrate that there was at least a certain layer of literacy among the nomads in the steppe both in their native scripts and Chinese, and there was a bureaucracy, as Barfield suggests, which was responsible for record keeping and administering the state. ${ }^{13}$

However, as mentioned above, the Khitan large script (thought to have been invented in 920 under the order of the first Khitan emperor Abaoji) was not fit for recording the Khitan language practically for linguistic reasons. Larger records such as book keeping and state documents required a more complicated language and vocabulary than epigraphs. So far, only around 1,000 Khitan large script characters, some of which are doubtful, have been discovered, mainly in stelae. In 925, after the arrival of Uighur emissaries to the Khitan court, the Khitan small script was created, modeled after the Uighur script. The outward appearance of the Khitan small script, however, does not resemble the Uighur script at all. In fact, scholars initially had difficulty in distinguishing it from the large Khitan script. But the logic of the small Khitan script closely resembles the logic of Korean Hangul script, which was invented in the $14^{\text {th }}$ century. It is safe to speculate that the Khitan small script was in wider use among the Khitans due to its practicality

13 Thomas Barfield, The Perilous Frontier: Nomadic Empires and China, 221 BC to AD 1757 (New York: Wiley, 1992). 
in recording the language. Until recently there were no manuscripts, printed books or any other materials written in the Khitan script, with the exception of Tao Zongyi’s (陶宗儀) book, which contained some examples of Khitan calligraphy. ${ }^{14}$ However, there are two more manuscripts worth mentioning. The first one is a manuscript found in Kyrgyzstan and brought over to Moscow and then to St. Petersburg, where it was identified as a book in Khitan large script. This manuscript was catalogued as "NOVA N 176". This manuscript was discovered in Kyrgyzstan in 1954 and was sent eventually to the St. Petersburg Institute of Oriental Manuscripts. It was thought to be the Jürchen script until 2010, when Zaytsev suggested that it was the Khitan, and that it most probably had been written during the time of Qara Khitai in Central Asia, since it was excavated in Kyrgyzstan. ${ }^{15}$ If this is the case, this manuscript proves two vital points. First of all, it proves that the Khitan script was in wider use than the epigraphs carved in stone. Just like Irk Bitik, which was written in Turkic runes, this manuscript proves that the Khitan script and language was in wider use than originally thought. It was written in a cursive style not attested to in any of the stone carvings or other artifacts before, which also proves that the script was well developed by the time it was written, and that it had a wide audience. According to Zaytsev, the manuscripts are excerpts from history books on the history of the Khitans. ${ }^{16}$ In this regard, it is significant that different styles of writing had developed, and that more general works on history were circulated even in the Qara Khitai state, which had been established in Central Asia by the fleeing Khitans headed by Yelü Dashi upon the collapse of the Liao State in the east. Secondly, the fact that this manuscript was found in Kyrgyzstan reveals the fact that it was widespread among the Khitans, as those who could flee the combined Song-Jürchen attack were not the main members of the Khitan court and the royal family, but were rather a collateral branch of the Yelü clan under Yelü Dashi. This demonstrates that the Khitan script was not limited to the Liao court for merely ceremonial use on the epigraphs. Further, the fact that the manuscript Nova N 176 was unearthed in the Qara Khitai area also supports this view, along with the fact that it was a living language by then, since a cursive script seems to have been developed and some new characters added. ${ }^{17}$

Another recently discovered manuscript is a bilingual Khitan-Uighur gloss which is held in Berlin, Germany. Although this manuscript is in bits and pieces, it reminds one of the Idiqut Dictionary which is an Uighur-Chinese dictionary for emissaries going to and coming from China for diplomatic or trade missions. ${ }^{18}$ Likewise, this manuscript with Uighur glosses identified in the Brandenburg Academy of Sciences and Humanities collection in 2002 probably served

14 Zongyi Tao, “輟耕錄 [Chuo Genglu],” chap. 12, accessed January 10, 2021, https://zh.wikisource.org/zh-hans /\%Е8\%ВС\%9F\%Е8\%80\%95\%Е9\%8С\%84.

15 Zaitsev, “Идентификация Киданьского Исторического Сочинения В Составе Рукописной Книги-Кодекса Nova H 176 Из Коллекции Ивр Ран И Сопутствующие Проблемы [Identifikatsiya Kidan’skogo Istoricheskogo Sochineniya V Sostave Rukopisnoy Knigi-Kodeksa Nova N 176 Iz Kollektsii Ivr Ran I Soputstvuyushchiye Problemy]," 169.

16 Ibid., 170.

17 Ibid., 173.

18 Mağrifet Kemal Yunusoğlu, Uygurca-Çince İdikut Sözlüğ̈̈ (Istanbul: Türk Dil Kurumu Yayınları, 2012). 
a similar function, that is, to teach the Khitan language to Uighurs and vice versa. ${ }^{19}$ If this is the case, this further proves that the Khitan script and language was not limited to the Khitan court's inner circles and epigraphs, but was learnt by Uighurs and probably other neighboring states' diplomats as well. In this case, the Khitans and Uighurs probably did not transact their relations in Chinese, which is assumed to be the lingua franca of diplomacy in East Asia. This manuscript still needs to be studied further and its place of origin needs to be verified. In any case, however, a Khitan text with an Uighur gloss was most probably written with the aim of teaching the Khitan language to Uighur speakers whatever the reasons for learning the language were. This demonstrates the wider use of the written Khitan language in official matters. This is further attested in Khitan language epigraphs written during and after the Liao Dynasty, examined by $\mathrm{Wu}$ and Janhunen. These seem to contain a vocabulary related to state affairs as well as titles pointing to a complicated administrative apparatus. In fact, it is recorded that Goryeo court sent a total of twenty pupils to learn the Khitan language. Although as Wittfogel and Feng highlight the failure of this attempt by pointing out that there was no one to read a letter in the Khitan language sent from Liao to Goryeo until some years afterwards, this shows that the Khitan script was studied, albeit unsuccessfully, by the Koreans and that it was used in Khitan diplomatic missions as well, although no artifacts have been recovered so far.

\section{Jin Period}

When the Jürchens rebelled against the Khitans and overthrew them, the Khitan vernacular and written languages did not disappear suddenly. For a while, the Khitan language seems to have enjoyed its formal status until the large and small Jürchen scripts, which were apparently modelled after the Khitan scripts, gradually supplanted the Khitan written language in the $12^{\text {th }}$ century. It is not certain when exactly the Jürchen scripts completely replaced the Khitan scripts and language in formal matters. However, the discovery of five Khitan language epitaphs belonging to the Jin period and the fact that Yelü Chucai, a famous Khitan scholar, was serving at an official capacity as a high ranking officer in the Jin court when the Mongols conquered Manchuria, along with many other Khitans, suggests that the Khitans were influential in the Jin bureaucracy despite the previous enmity. Yelü Chucai is also reported to have spoken and written in Khitan. ${ }^{20}$ Aside from this famous personality, there were many other Khitans from the Yelü clan as well as the Uighur Xiao clan, among others, serving within the ranks of the Jin officials who knew the Khitan language. And the discovery of five epitaphs written in the Khitan language during the Jin dynasty, the latest of which is dated to 1175, approximately just

19 Zaitsev, “Рукописная Книга Большого Киданьского Письма Из Коллекции Института Восточных Рукописей PAH [Rukopisnaya Kniga Bol'shogo Kidan'skogo Pis'ma Iz Kollektsii Instituta Vostochnykh Rukopisey RAN]," 137.

20 Alexander Lvovich Ivliev, “Соотношение Культур Империи Ляо и Киданей [Sootnosheniye Kul’tur Imperii Lyao i Kidaney]," Археология и Этнография Народов Дальнего Востока. Сборник Научных Трудов. Владивосток [Arkheologiya i Etnografiya Narodov Dal'nego Vostoka. Sbornik Nauchnykh Trudov. Vladivostok], 1984,67 . 
four decades before the arrival of the Mongols, shows that the Khitan language most probably was not only spoken, but also written throughout the Jin period. The first of these epitaphs is actually dated to the very year that the Jin Dynasty was established, in 1115. This epitaph is a memorial stone erected for a Yelü princess. ${ }^{21}$ The second epitaph, dated to 1134, is actually more important, since it is a record of a Jürchen prince's journeys entitled “大金皇弟都統經 略郎君行路: The Journey Records of the Younger Imperial Brother of Great Jin” which, as the title suggests, records the journeys of the younger brother of the first Jürchen emperor, who was an important figure. ${ }^{22}$ There is another similar epitaph dated to 1170 , which was erected in honor of a Jin general who passed away (鎮國上將軍). While this is not the latest epitaph that has been discovered (the latest one is dedicated to Xiao Jushi, an Uighur aristocrat from the Xiao Consort Clan of the previous Liao Dynasty dated1175), this epitaph shows that as late as the 1170 s the Khitan language continued to be used also by Jürchens, even though they had already developed their own scripts by then. ${ }^{23}$ While it is understandable that an aristocrat from the Uighur Xiao clan who was closely related to the Khitan Yelü clan through marriage preferred to have his tomb stone inscribed in the Khitan language, the fact that a Jürchen general's tomb stone was also inscribed in the Khitan language as late as 1170 demonstrates that the Khitan script was popular even among the Jürchens by the end of the $12^{\text {th }}$ century.

While we have no artifacts of comparable size to the Liao and Jin period inscriptions for the Yuan period, Yelü Chucai and other Khitan officials are reported to have continued the use of the language. As late as the late Yuan period, we see examples of Khitan script as in the case of Tao Zongyi’s Chuo Genglu (軙耕錄) which contains some calligraphy in Khitan. ${ }^{24}$

\section{Conclusion}

The Khitans, who spoke a language related to Mongol, were an insignificant group until the $8^{\text {th }}$ century. Beginning from the $8^{\text {th }}$ century onwards, they began to consolidate their power, despite attacks from their neighbors. Their unification began following the An Lushan rebellion and the fall of the Tang Dynasty. The Khitans were organized as a tribal confederation. But both the leaders of the confederation and the tribal leaders were elected, which hindered a unified state around a charismatic and strong leader like the Türk and Uighur Qaghans. But when Yelü Abaoji (Abaqai?) united the Khitans and the surrounding Turkic and Tungus tribes, he not only established the Liao dynasty, but also laid claim to the Türk and Uighur legacies on the political sphere. They not only took brides from the Uighur Xiao clan, one of the few aristocratic Uighur clans who fled to Manchuria following the fall of the Uighur Qaghanate, but also created their own writing systems like the Türks and Uighurs and erected stelae

21 Wu and Janhunen, New Materials on the Khitan Small Script A Critical Edition of Xiao Dilu and Yelü Xiangwen, 26.

22 Ibid., 26-27.

23 Ibid., 27.

24 Tao, "v [Chuo Genglu]." 
written in Khitan script. Although the stelae have been mostly deciphered to date, translation efforts and reconstruction of the language still continue, in addition to new materials surfacing in both archeological findings as well as archival discoveries. Although this paper mainly aimed to make a brief introduction to the current state of affairs, it does not and, in a limited space, cannot cover in detail all the materials so far discovered. However, the decipherment and the translation of the new materials will no doubt contribute to the historical research on the Khitans as well as the other steppe tribes and peoples in the area. Considering the fact that Chinese language materials still lack in details, Khitan materials might in the future shed a better light on the history of the steppe during the $10^{\text {th }}-13^{\text {th }}$ centuries, which was a time of great developments leading to the rise of the Mongol empire. Unfortunately, however, due to the lack of sources, this period has been studied in less detail than others.

Peer-review: Externally peer-reviewed.

Conflict of Interest: The author has no conflict of interest to declare.

Grant Support: The author declared that this study has received no financial support.

\section{References}

Atik, Kubilay. "A Comparison of Komnenos Era Byzantine and Song Era Chinese Diplomacy with Nomadic Neighbors.” Atatürk Üniversitesi Türkiyat Araştırmaları Enstitüsü Dergisi 70, no. 1 (2021): 343-58. http:// www.turkiyatjournal.com/DergiTamDetay.aspx?ID=4433.

Atik, Kubilay. “Ortaçă̆ Bozkır Devletlerinde Hayvancılık Üzerine Yasalar: Tangut Devleti Örneği.” Erzincan Üniversitesi Sosyal Bilimler Enstitüsü Dergisi 13, no. 2 (2020): 183-98. doi:https://doi.org/10.46790/ erzisosbil.798191.

Barfield, Thomas. The Perilous Frontier: Nomadic Empires and China, 221 BC to AD 1757. New York: Wiley, 1992.

Ivliev, Alexander Lvovich. “Соотношение Культур Империи Ляо и Киданей [Sootnosheniye Kul’tur Imperii Lyao i Kidaney].” Археология и Этнография Народов Дальнего Востока. Сборник Научных Трудов. Владивосток [Arkheologiya i Etnografiya Narodov Dal'nego Vostoka. Sbornik Nauchnykh Trudov. Vladivostok], 1984.

Kane, Daniel. The Kitan Language and Script. Vol. 166. Leiden: Brill, 2009.

Kradin, Nikolai N., and Stanislav Prokopets. Великая Киданьская Стена: Северо-Восточный Вал ЧингисХана. Moscow: Nauka, 2019.

Rudov, L. N. “Проблемы Киданьской Письменности.” Сов. Этнография, по. 1 (1963).

Shavkunov, Vladimir Ernstovich. “К Вопросу о Расшифровке Малой Кидань-Чжурчжэньском Письменности [K Voprosu o Rasshifrovke Maloy Kidan'-Chzhurchzhen'skom Pis'mennosti: On the Issue of Deciphering Khitan Small-Jurchen Writing].” Eppgrafnka Vostoka 15 (1963).

Shimunek, Andrew E. Towards a Reconstruction of the Kitan Language, with Notes on Northern Late Middle Chinese Phonology. Bloomington: Indiana University, Department of Linguisitcs and the Department of Central Eurasian Studies, 2007. 
Skaff, Jonathan Karam. "Barbarians at the Gates? The Tang Frontier Military and the An Lushan Rebellion." War \& Society 18, no. 2 (2000): 23-35. http://www.maneyonline.com/doi/abs/10.1179/072924700791201658.

Standen, Naomi. Unbounded Loyalty: Frontier Crossings in Liao China. Honolulu: University of Hawaii Press, 2007.

Tan, John. “О ДВУХ ЗНАКАХ КИДАНЬСКОГО ПИСЬМА, ОТНОСЯЩИХСЯ К ЖЕЛЕЗУ.” АСТА LINGUISTICA PETROPOLITANA. ТРУДЫ ИНСТИТУТА ЛИНГВИСТИЧЕСКИХ ИССЛЕДОВАНИЙ 11, no. 3 (2015): 465-70. http://elibrary.ru/item.asp?id=25462828.

Tao, Zongyi. “輟耕錄 [Chuo Genglu].” Accessed January 10, 2021. https://zh.wikisource.org/zh-hans/\%E8 $\% \mathrm{BC} \% 9 \mathrm{~F} \% \mathrm{E} 8 \% 80 \% 95 \% \mathrm{E} \% \% 8 \mathrm{C} \% 84$.

Taskin, Vsevolod Sergeyevich. “Опыт Дешифровки Киданьской Письменности [Opyt Deshifrovki Kidan’skoy Pis'mennosti: Experience Deciphering Khitan Script].” Narody Azii i Afrikii, no. 1 (1963).

Vovin, Alexander. "Did the Xiongnu Speak a Yeniseian Language.” Central Asiatic Journal 44, no. 1 (2000): 87-104.

Wu, Yingzhe, and Juha Janhunen. New Materials on the Khitan Small Script A Critical Edition of Xiao Dilu and Yelü Xiangwen. Corpus Scriptorum Chitanorum 1. Kent: Global Oriental, 2010.

Yunusoğlu, Mağrifet Kemal. Uygurca-Çince İdikut Sözlüğü. Istanbul: Türk Dil Kurumu Yayınları, 2012.

Zaitsev, Vasiliy Petrovich. "Рукописная Книга Большого Киданьского Письма Из Коллекции Института Восточных Рукописей РАН [Rukopisnaya Kniga Bol'shogo Kidan'skogo Pis'ma Iz Kollektsii Instituta Vostochnykh Rukopisey RAN]." Письменные Памятники Востока [Pis 'mennyye Pamyatniki Vostoka: Written Monuments of the Orient], no. 2 (2011): 15.

Zaitsev, Vyacheslav Petrovich. “Идентификация Киданьского Исторического Сочинения В Составе Рукописной Книги-Кодекса Nova H 176 Из Коллекции Ивр Ран И Сопутствующие Проблемы [Identifikatsiya Kidan'skogo Istoricheskogo Sochineniya V Sostave Rukopisnoy Knigi-Kodeksa Nova N 176 Iz Kollektsii Ivr Ran I Soputstvuyushchiye Problemy].” Acta Linguistica Petropolitana-Trudy Instituta Lingvisticheskikh Issledovaniy 11, no. 3 (2015): 167-208. http://www.academia.edu/download/40789881/ zaytsev_2015.pdf. 